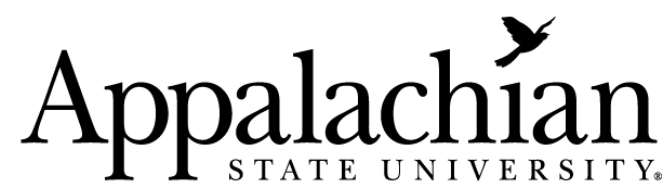

B O O N E, NORT H C A R O L N A

\section{Topoedaphic and Morphological Complexity of Foliar Damage and Mortality Within Western Juniper (Juniperus Occidentalis Var. Occidentalis) Woodlands Following an Extreme Meteorological Event}

\author{
By: Peter T. Soule \& Paul A. Knapp
}

\begin{abstract}
Aim An extreme early season freeze event in October 2002 resulted in significant foliar damage and/or mortality within western juniper woodlands. We identify the geographical patterns of tree damage based on morphological, topographical and edaphic parameters, and discuss the ecological implications of this event.

Methods: We sampled trees on four matched pairs of disturbed and minimally disturbed study sites within the core area of tree damage. We collected information about age, morphology (height, basal area, level of foliar damage), and topographic position (elevation, slope, aspect) for each tree sampled using dendroecological and GPS/GIS procedures. We collected plot-level data on tree density and degree of cover for shrubs and grasses. We used a series of MannWhitney, Kruskal-Wallis and Wilcoxon tests and graphical analyses to determine if significant differences exist in our collected variables both between matched pairs and within our disturbed sites.

Results: Topographically, we found that aspect was a critical element regulating damage, with trees in colder microenvironments (north-westerly slopes) experiencing less damage because they were further along in the annual process of cold-hardening. The majority of damaged trees were found in areas of higher density and more even age structure that are typical of recent juniper afforestation. Morphologically, we show that trees with greater basal areas and/ or less stature were less likely to have foliar damage, consistent with winter cavitation.

Main conclusions: Our results show that the spatial pattern of damage was closely related to topography and tree morphology, parameters that, in turn, correspond closely to differences between the historical locales of western juniper and juniper woodlands that have emerged in a 100+ year period of rapid afforestation. This freeze event fits the criteria for a large, infrequent disturbance in that it was spatially complex and may act as an endogenous factor that can contribute to stand maintenance
\end{abstract}

Peter T. Soule \& Paul A. Knapp (2007) "Topoedaphic and Morphological Complexity of Foliar Damage and Mortality Within Western Juniper (Juniperus Occidentalis Var. Occidentalis) Woodlands Following an Extreme Meteorological Event" Journal of Biogeography Volume 34: pp.1927-1937. Version of Record Available From (www.onlinelibrary.wiley.com) 


\section{Introduction}

The spatial heterogeneity of many landscapes can be attributed in part to rare, but severe, ecological disturbances that affect large areas. Two events in the latter half of the 20th century, the eruption of Mount St Helens in 1980 and the wildfires in Yellowstone National Park 1988, serve as classic examples of what have been identified as 'large,

infrequent disturbances' (Turner \& Dale, 1998: 493). These events can be temporally exceptional, such as the Mount St Helens eruption, which affected many long-lived species such as old-growth conifers, and/or geographically extensive, such as the widespread fires that burned approximately $36 \%$ of Yellowstone National Park (Stone, 1998). Despite the destructiveness of these events, they ensure vegetation heterogeneity (Turner et al., 2003; Dale et al., 2005), and provide reasons for complex vegetation patterns across a landscape. Here we document evidence of a recent large, infrequent disturbance to western juniper woodlands in the interior Pacific Northwest, and discuss the spatial complexity of the event.

In late October 2002, extremely low temperatures occurred throughout much of the core range of western juniper (Juniperus occidentalis Hook. var. occidentalis). Temperatures below $-15^{\circ} \mathrm{C}$ were recorded at numerous climate stations east of the Cascade Mountains from 40 to $45^{\circ} \mathrm{N}$, with some stations recording temperatures below $-20^{\circ} \mathrm{C}$ (Knapp \&

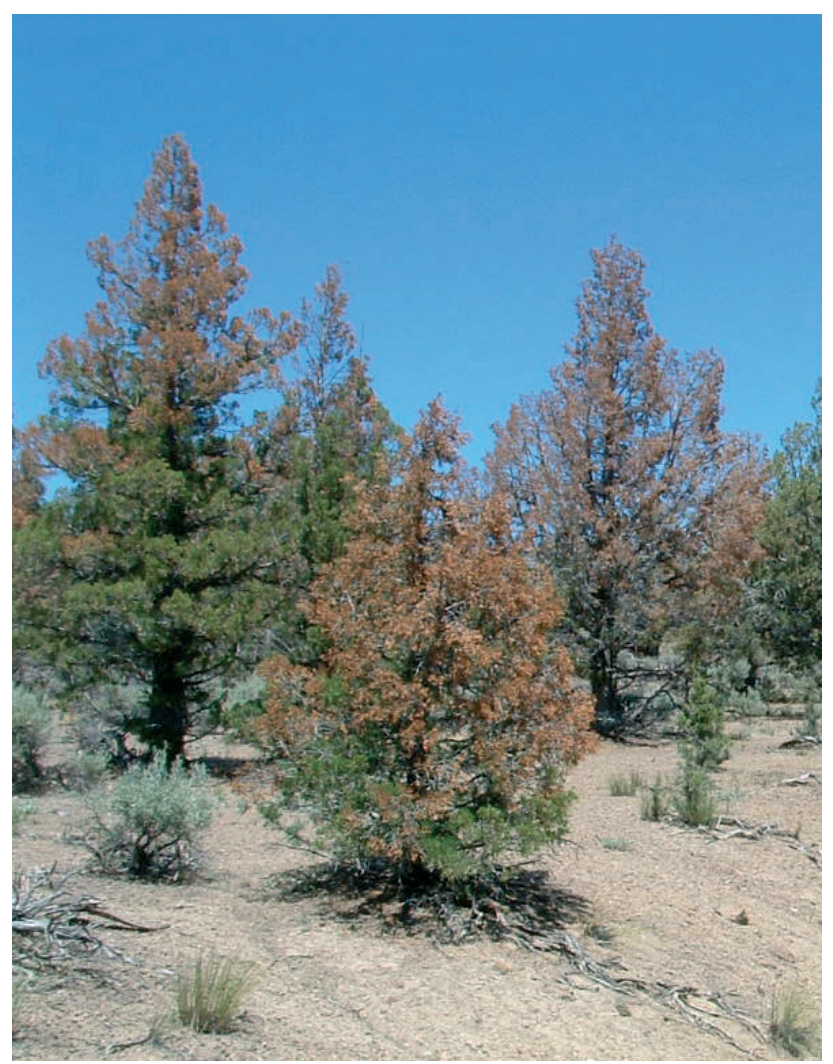

Soulé, 2005). While these low temperatures are common within the range of western juniper during winter, they are extremely rare during autumn. By late spring 2003, range management personnel noticed a dramatic change in the appearance of western juniper woodlands in some areas (T. Deboodt, OSU Crook County Extension Agent, personal communication; R. Halvorson, District Botanist, Prineville, OR, Bureau of Land Management, personal communication), with over half of the trees in the most affected areas experiencing either partial dieback on the outer portion of branches, complete dieback of the top one-third to one-half of the tree with the lower canopy needles also partially impacted, or complete mortality (Fig. 1). Plant pathologists from Oregon State University analysed samples of dead foliage collected after the freeze event and concluded that there 'was no evidence of any diseases or pests' (Savonen, 2003: 1). With no other logical cause of such large-scale impacts to juniper woodlands, the conclusion was that the extreme freeze event of the prior autumn was responsible
Figure 1 Examples of foliar damage to or mortality of western juniper trees at the Salt Creek Disturbed site, July 2004 (photograph by authors). 
(Savonen, 2003; R. Halvorson, personal communication). Specifically, the affected trees were probably damaged by cavitation (Sharrow, 2004), where freezing of the xylem cells forces air into the xylem water column (Davis et al., 1999; Pittermann \& Sperry, 2006). The subsequent embolism 'impedes water transport', leading to foliar injury (Pittermann \& Sperry, 2006: 374). While conifers are less susceptible to freeze-induced cavitation than other tree species because their tracheids have a small diameter, multiple species of juniper have been shown to experience freeze-induced cavitation from a single freeze event when that event is preceded by drought conditions (Willson \& Jackson, 2006).

The timing of the cold event in the interior Pacific Northwest occurred before many western juniper trees were sufficiently cold-hardened. Thus, in the absence of this protective physiological mechanism for extremely cold conditions, trees were damaged or killed by late spring 2003. The impacts were readily apparent in summer 2004, when we conducted our investigation. While there were no detailed surveys taken to assess the spatial extent of the foliar damage, Bureau of Land Management (BLM) personnel estimated that c. 3\% (T. Deboodt, personal communication), or 110,000 ha, of the 3.6 million ha of western juniper woodlands (Miller et al., 2005) were affected, with complex spatial patterns of dieback/mortality present.

Western juniper trees are common throughout the interior Pacific Northwest. While historically relegated to higher elevations, steeper slopes and rocky outcrops, where fire cannot easily spread (Miller \& Rose, 1999), within the past 100 years there has been an exceptional expansion of the species (Miller \& Rose, 1995, 1999; Gedney et al., 1999; Soulé et al., 2004) such that substantial populations now occur on virtually every type of terrain present throughout their range. Because of the topographical and ecological diversity of the current distribution of western juniper, we theorized that the spatial pattern of foliar damage and mortality would be closely linked to a suite of micro-environmental conditions related to slope, elevation, aspect or edaphic conditions. However, our discussions with BLM personnel, and our initial observations of the spatial pattern of foliar damage, suggested that the pattern was more complex and not so easily classified, as some level of foliar damage was evident on most aspects, at higher and lower elevations, and on flat as well as steeply sloping terrain.

In a prior study, we documented the meteorological parameters of the extreme freeze, showing that it was an unusual event with a statistical recurrence interval, calculated for daily low temperature on 31 October 2002, often in excess of 500 years (Knapp \& Soulé, 2005). Disturbances of this magnitude are notable from an ecological perspective because they may help explain both species range distributions and complex landscape patterns not easily attributed to smaller and more frequent disturbances. For example, the distribution of creosote bush (Larrea tridentata Cov.) in central New Mexico is believed to be controlled, in part, by extreme freeze events
(Martinez-Vilalta \& Pockman, 2002). As these events 'are not well understood' (Turner \& Dale, 1998: 493), examining the ecological consequences of the October 2002 freeze provides insight on an event that will leave a multi-decade or longer imprint on the western juniper woodlands of the interior Pacific Northwest.

\section{METHODS}

\section{Field collection}

With assistance from ecologists working for the BLM, we travelled within the core range (roughly $41-45^{\circ} \mathrm{N}, 119$ $121.5^{\circ} \mathrm{W}$ ) of tree impact and surveyed the overall extent of the damage. As there appeared to be a complex pattern of foliar damage, with some areas severely affected and other, adjacent areas substantially less affected, we established criteria for sampling areas where the majority of adult trees had visual foliar damage ('disturbed', $>50 \%$ of trees with $>10 \%$ foliar damage), and for comparison used the closest nearby site with minimal impacts ('minimally disturbed', $\mathrm{MD},>75 \%$ of trees with $<10 \%$ foliar damage). The extent of visual foliar damage to trees was such that true control sites, where no trees appeared to have damage, did not exist. We selected four matched pairs of disturbed and MD study sites (Fig. 2; Table 1). BLM personnel familiar with the region confirmed that all the sites selected for sampling had not been recently burned, logged, mechanically treated, or affected by other anthropogenic activities, and that no known regional-scale, non-climatic cause of western juniper mortality was operative between October 2002 and August 2004.

Our sampling procedures at each of the eight sites began at a randomly selected starting point, where we placed five 0.05 -ha circular plots along a line transect at $c .100-\mathrm{m}$ intervals. We recorded the latitude and longitude of the plot centre using a global positioning system (GPS), with accuracy $<10 \mathrm{~m}$. To determine density, we counted all adult juniper $(>1 \mathrm{~m}$ high and with all needle, as opposed to scaly, foliage) within each plot, distinguishing between trees physically affected $(\geq 10 \%$ foliar damage) and not physically affected $(<10 \%$ foliar damage). We used a survey tape to place a $25-\mathrm{m}$ transect through each plot centre and along the dominant slope contour. We measured cover for shrubs and grasses by recording distance along the tape that intercepted shrub or grass cover.

Within each disturbed plot, we obtained core samples using a stratified random sample by selecting the six adult trees closest to the plot centre $(n=30$ total). We collected two or more increment cores from each tree using standard, non-destructive dendroecological field techniques (Phipps, 1985). We recorded information about each tree, including basal area, tree height and presence of fire scars or other damage. Because we wanted to obtain accurate estimates of tree age, we sampled each tree bole typically at $\leq 30 \mathrm{~cm}$ high and recorded the sample height. On the disturbed sites, we estimated the percentage of foliar damage (dead, 


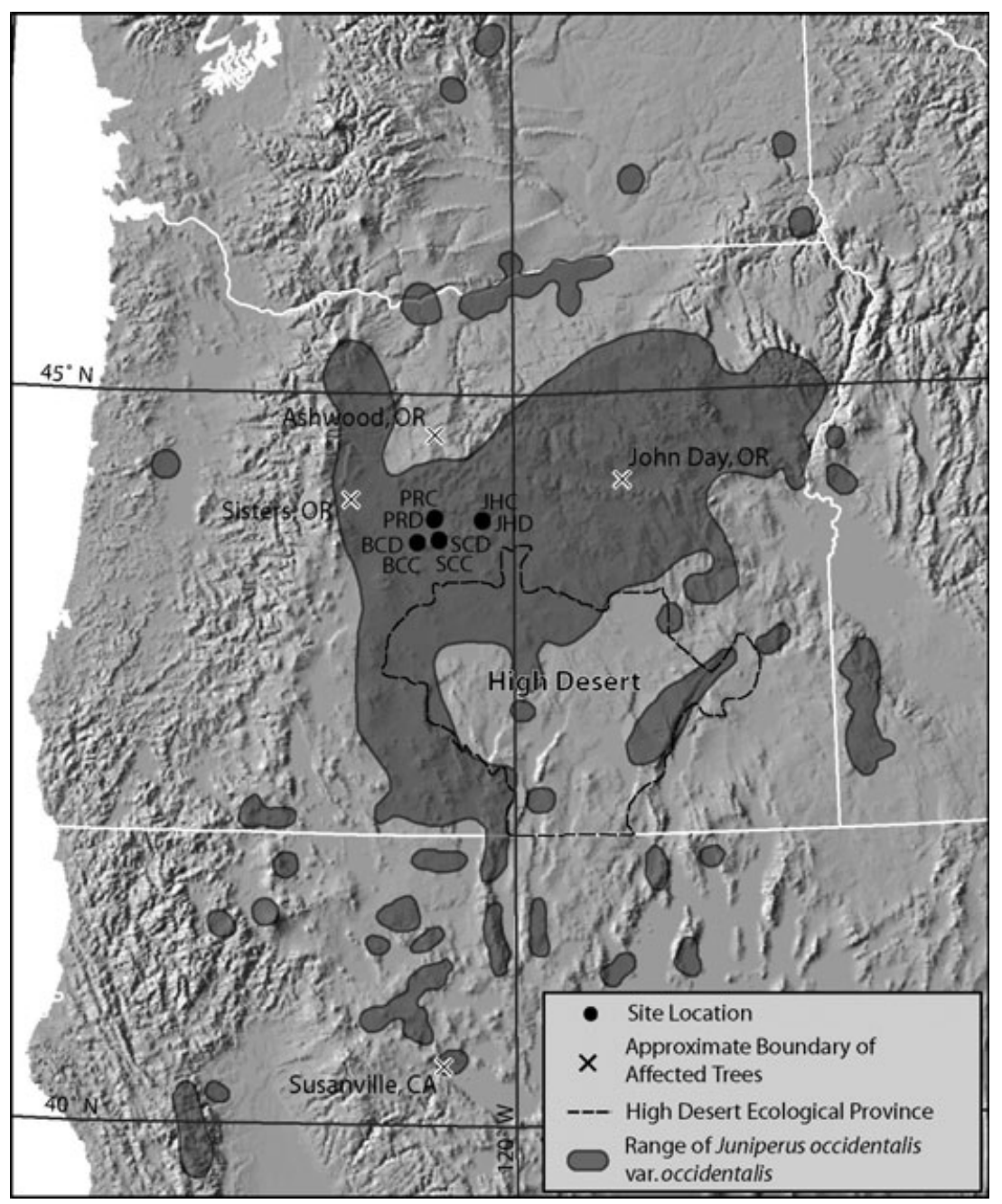

Figure 2 Geographical distribution of western juniper, the approximate boundaries of areas affected by the freeze/drought, locations of sample sites (see Table 1), and the High Desert Ecological Province of Oregon.

Table 1 Study site location and soils information.

\begin{tabular}{|c|c|c|c|}
\hline Site name and abbreviation & Latitude/longitude ${ }^{*}$ & Soil type name & Soil classification description \\
\hline Prineville Reservoir Disturbed (PRD) & $44.145^{\circ} / 120.748^{\circ}$ & $\begin{array}{l}\text { Searles-Lickskillet } \\
\text { complex }\end{array}$ & $\begin{array}{l}\text { Loamy-skeletal, mixed, superactive, } \\
\text { mesic Lithic Haploxerolls }\end{array}$ \\
\hline $\begin{array}{l}\text { Prineville Reservoir Minimally } \\
\text { Disturbed (PRC) }\end{array}$ & $44.160^{\circ} / 120.741^{\circ}$ & $\begin{array}{l}\text { Anatone-Bocker } \\
\text { complex }\end{array}$ & $\begin{array}{l}\text { Loamy-skeletal, mixed, superactive, } \\
\text { frigid Lithic Haploxerolls }\end{array}$ \\
\hline Bear Creek Disturbed (BCD) & $43.993^{\circ} / 120.905^{\circ}$ & Housetake & $\begin{array}{l}\text { Coarse-loamy, mixed, superactive, } \\
\text { mesic Vitritorrandic Haploxerolls }\end{array}$ \\
\hline Bear Creek Minimally Disturbed (BCC) & $43.986^{\circ} / 120.906^{\circ}$ & Polkbutte & Ashy, glassy frigid Vitrandic Haploxerolls \\
\hline Salt Creek Disturbed (SCD) & $44.009^{\circ} / 120.699^{\circ}$ & $\begin{array}{l}\text { Searles-Lickskillet } \\
\text { complex }\end{array}$ & $\begin{array}{l}\text { Loamy-skeletal, mixed, superactive, } \\
\text { mesic Lithic Haploxerolls }\end{array}$ \\
\hline Salt Creek Minimally Disturbed (SCC) & $44.003^{\circ} / 120.701^{\circ}$ & $\begin{array}{l}\text { Searles-Lickskillet } \\
\text { complex }\end{array}$ & $\begin{array}{l}\text { Loamy-skeletal, mixed, superactive, } \\
\text { mesic Lithic Haploxerolls }\end{array}$ \\
\hline Juniper Hills Disturbed (JHD) & $44.135^{\circ} / 120.293^{\circ}$ & $\begin{array}{l}\text { Searles-Lickskillet } \\
\text { complex }\end{array}$ & $\begin{array}{l}\text { Loamy-skeletal, mixed, superactive, } \\
\text { mesic Lithic Haploxerolls }\end{array}$ \\
\hline Juniper Hills Minimally Disturbed (JHC) & $44.145^{\circ} / 120.288^{\circ}$ & Drakebutte & $\begin{array}{l}\text { Loamy-skeletal, mixed, superactive, } \\
\text { frigid Vitritorrandic Haploxerolls }\end{array}$ \\
\hline
\end{tabular}

${ }^{\star}$ Latitude and longitude at the middle plot (plot 3) at each site.

reddish-orange needles) and placed each tree sampled into categories: $1=10-25 \%$ foliar damage, $2=26-50 \%, 3=51-$ $75 \%, 4=76-100 \%$. Trees with $<10 \%$ foliar damage were not sampled. We repeated the procedures for the MD sites, except that we sampled only from trees with no or minimal $(<10 \%)$ visible foliar damage. 


\section{Laboratory methods}

We processed the collected core samples using a standard technique whereby each sample is mounted and sanded until the cellular structure is clear under magnification. Each core sample was then cross-dated using the list method (Phipps, 1985; Yamaguchi, 1991). Cross-dating accuracy was assured by using diagnostics available through the program COFECHA (Holmes, 1983; Grissino-Mayer, 2001) after measurement of ring widths at a precision of $0.01 \mathrm{~mm}$.

We began with the interior date of each tree to obtain the year of establishment for each core. On samples where we did not reach pith, but a clear pattern of tree-ring curvature was present, we used pith locators (Applequist, 1958) to estimate the number of rings required to reach pith, and then added these years to the age. As we did not have permission to destroy live vegetation, and it is not possible to non-destructively sample a tree at ground level, we used an additional adjustment to determine the final tree age. Accordingly, we adjusted for the height at which we sampled on the tree bole using a regression formula that predicted tree age as a function of height for the Powell Butte Research Natural Area, a comparable site within c. 20-30 km of three of our four study sites (Soulé et al., 2004). Soulé et al. (2004) obtained this formula by first measuring the height, then harvesting 43 juvenile western juniper trees at ground level and cross-dating the samples prior to modelling the relationship between age and height. The Powell Butte model provides age/height estimates within the range expected for juvenile western juniper (Bedell et al., 1993; Miller et al., 1995).

\section{GIS procedures}

We downloaded 10-m-resolution digital elevation models (DEMs) for the areas encompassing our study sites (Geo Community, 2006). We used the Surface Analysis function in 3D ANAlyst (ESRI, Redlands, CA, USA, 2006) to calculate slope (degrees) and aspect (degrees) from the DEM. We imported the DEM, slope and aspect data sets into ArCMAP (ESRI, 2006) and overlaid the study-site GPS points (the centre of each 0.05-ha plot) onto these layers. At the pixel level, we zoomed into each point and identified the corresponding pixel values for slope, elevation $(\mathrm{m})$ and aspect.

\section{Soil classification}

We classified soils by overlaying the eight sites/40 plots on 1:24,000 soil maps and determining the accompanying soil type identified by the Natural Resources Conservation Service (NRCS, 2003). Our sites are in Crook County, Oregon where the soils classification is inaccessible electronically. Accordingly, we used draft copies of the soil classification provided by the Prineville, Oregon BLM district office.

\section{Statistical and graphical analyses}

Because the tree-age data were not normally distributed, we used the nonparametric Mann-Whitney test to determine if there were significant differences in tree age between the disturbed and MD sites using tree-level data $(n=102$ disturbed sites, $n=109 \mathrm{MD}$ sites). In conjunction, we used Levene's test to check for equality of variance. We used the 0.05 significance level for all tests. To develop a timeline of tree establishment, we first separated the data into disturbed and MD groups. We then placed each dateable tree $(15 \%$ of the disturbed-sample trees and $9.2 \%$ of the MD-sample trees were undatable because of heart rot) into a decadal bin and calculated the percentage of trees established per decade. We present these data graphically in association with the difference-of-means test.

We sorted the data from the four disturbed sites into four groups, based on the level of foliar damage observed, and calculated mean ages for each group to determine if there was any relationship between the degree of disturbance and tree age. We compared these ages using the Kruskal-Wallis test. For each site, we calculated the per hectare density of mature western juniper that were visibly affected $(\geq 10 \%$ foliar damage) and not affected ( $<10 \%$ foliar damage). We used the Mann-Whitney test to compare the density distribution between disturbed and MD sites at the plot level $(n=20)$.

For the combined disturbed and MD sites, we calculated the mean basal area, mean height of trees, elevation and slope. We compared the tree-level data using Mann-Whitney tests. We compared elevation, degree of slope, and aspect associated with each tree sampled between disturbed and MD sites to determine if any of these three elements was a factor in the observed patterns of foliar damage. For slope and elevation, we compared the disturbed and MD site trees using a MannWhitney test. For aspect, we plotted the pattern on a compass rose containing concentric circles corresponding to degree of foliar damage.

For each site, we calculated cover for grasses, shrubs and open ground from our transect samples. We tested for significant differences for each category using a matched-pairs Wilcoxon test (e.g., BCD matched with BCC, $n=4$; Table 1). For the disturbed sites, we sorted the data by disturbance category and calculated mean age, height and basal area of the trees, and mean elevation and degree of slope within the plots the trees were sampled from. We compared these using a Kruskal-Wallis test.

\section{RESULTS}

Our initial impression that no area completely escaped the freeze event that caused foliar damage to western juniper (Fig. 3) was confirmed by our density count (Table 2). We determined that $62.5 \%$ of the trees in our disturbed-site density count had foliar damage exceeding $10 \%$, while $84.6 \%$ of the trees in our MD areas had no or minimal $(<10 \%)$ foliar 
Table 2 Comparison of disturbed vs. minimally disturbed sites.

\begin{tabular}{|c|c|c|c|c|c|c|c|}
\hline \multirow[b]{2}{*}{ Variable } & \multicolumn{7}{|c|}{ Study site and sample size } \\
\hline & $\begin{array}{l}\mathrm{BCD}(27) / \\
\mathrm{BCC}(24)\end{array}$ & $\begin{array}{l}\text { JHD (20)/ } \\
\text { JHC (29) }\end{array}$ & $\begin{array}{l}\text { PRD (30)/ } \\
\text { PRC (27) }\end{array}$ & $\begin{array}{l}\operatorname{SCD}(25) / \\
\operatorname{SCC}(29)\end{array}$ & $\begin{array}{l}\text { All disturbed (102)/ } \\
\text { all MD (109) }\end{array}$ & $P$ & $\begin{array}{l}\text { Sample size/ } \\
\text { test used }\end{array}$ \\
\hline \multicolumn{8}{|l|}{ Age (years before 2004) } \\
\hline \multicolumn{8}{|c|}{ Mean age } \\
\hline Disturbed sites & 116 & 130 & 117 & 97 & 115 & & $n=102 / 109$ \\
\hline MD sites & 154 & 89 & 146 & 105 & 123 & 0.001 & Mann-Whitney \\
\hline \multicolumn{8}{|l|}{ Age SD } \\
\hline Disturbed sites & 35.0 & 30.9 & 30.0 & 22.1 & 31.5 & & $n=102 / 109$ \\
\hline MD sites & 150.8 & 24.9 & 123.7 & 42.6 & 99.5 & 0.006 & Levene's \\
\hline \multicolumn{8}{|l|}{ Density } \\
\hline \multicolumn{8}{|l|}{ Disturbed sites } \\
\hline Foliar damage & 9 & 62 & 59 & 38 & 168 & & $n=20$ \\
\hline No foliar damage & 5 & 3 & 11 & 14 & 33 & 0.000 & Mann-Whitney \\
\hline \multicolumn{8}{|l|}{ MD sites } \\
\hline Foliar damage & 35 & 5 & 16 & 45 & 101 & & $n=20$ \\
\hline No foliar damage & 41 & 32 & 39 & 43 & 155 & 0.046 & Mann-Whitney \\
\hline \multicolumn{8}{|c|}{ Slope, elevation, dominant aspect } \\
\hline \multicolumn{8}{|c|}{ Slope $\left(^{\circ}\right)$} \\
\hline Disturbed sites & 5.5 & 3.5 & 18.4 & 6.2 & 9.1 & & $n=102 / 109$ \\
\hline MD sites & 8.7 & 20.0 & 7.3 & 6.0 & 10.6 & 0.000 & Mann-Whitney \\
\hline \multicolumn{8}{|l|}{ Elevation (m) } \\
\hline Disturbed sites & 1151 & 1060 & 1177 & 1089 & 1126 & & $n=102 / 109$ \\
\hline MD sites & 1187 & 1147 & 1332 & 1099 & 1189 & 0.000 & Mann-Whitney \\
\hline \multicolumn{8}{|l|}{ Dominant aspect } \\
\hline Disturbed sites & NW & $\mathrm{S}$ & SE & SSE & S & & \\
\hline MD sites & WNW & NNW & WNW & WNW & NW & & \\
\hline \multicolumn{8}{|l|}{ Basal area and height } \\
\hline \multicolumn{8}{|l|}{ Basal area $\left(\mathrm{cm}^{2}\right)$} \\
\hline Disturbed sites & 736.4 & 681.3 & 509.0 & 459.3 & 590.8 & & $n=109 / 102$ \\
\hline MD sites & 931.3 & 322.7 & 750.5 & 574.9 & 629.8 & 0.004 & Mann-Whitney \\
\hline \multicolumn{8}{|l|}{ Height $(\mathrm{cm})$} \\
\hline Disturbed sites & 568.3 & 673.0 & 570.0 & 478.9 & 567.6 & & $n=109 / 102$ \\
\hline MD sites & 384.8 & 429.8 & 441.4 & 550.6 & 454.8 & 0.000 & Mann-Whitney \\
\hline \multicolumn{8}{|l|}{ Percentage cover } \\
\hline \multicolumn{8}{|l|}{ Grass } \\
\hline Disturbed sites & 8.5 & 9.7 & 26.1 & 8.0 & 13.1 & & $n=4$ \\
\hline MD sites & 13.3 & 23.5 & 9.9 & 4.7 & 12.9 & 0.999 & Matched Wilcoxon \\
\hline \multicolumn{8}{|l|}{ Shrub } \\
\hline Disturbed sites & 8.5 & 3.0 & 5.8 & 0.6 & 4.5 & & $n=4$ \\
\hline MD sites & 5.9 & 2.8 & 2.5 & 0.3 & 2.9 & 0.068 & Matched Wilcoxon \\
\hline \multicolumn{8}{|l|}{ Open } \\
\hline Disturbed sites & 83.0 & 87.3 & 68.1 & 91.3 & 82.4 & & $n=4$ \\
\hline MD sites & 80.8 & 73.6 & 87.6 & 95.0 & 84.3 & 0.715 & Matched Wilcoxon \\
\hline
\end{tabular}

damage. The density of mature juniper in the disturbed areas was $1076 \mathrm{ha}^{-1}$, while the density in the MD areas was $752 \mathrm{ha}^{-1}$ (Table 2).

Trees in the MD areas were significantly older than those in the disturbed areas, and had an age distribution that exhibited roughly three times the variance (Table 2; Fig. 4). On the MD sites, $11.9 \%$ of the trees were established prior to 1800 and $7.3 \%$ after 1950, while in the disturbed areas the percentages were 2 and 0 , respectively. The physical characteristics of the trees were also significantly different between disturbed and
MD sites (Table 2), as disturbed-site trees averaged over a metre taller, but had slightly less basal area. For all MD-site trees, the mean elevation and slope were significantly greater than those for disturbed-site trees (Table 2). Our examination of cover differences between disturbed and MD sites showed them to be similar, with no significant differences in grass or shrub cover (Table 2).

Aspect was critically important to the degree of foliar damage observed (Fig. 5). All the MD site trees $(<10 \%$ foliar damage) occurred on slopes with azimuths from $251^{\circ}$ (WSW) 
Figure 3 Widespread foliar damage/mortality of western juniper in Crook County (central) Oregon, July 2004. Younger individuals $(<100$ years $)$ in the foreground on a lower, southerly slope have widespread foliar damage (photograph by authors).

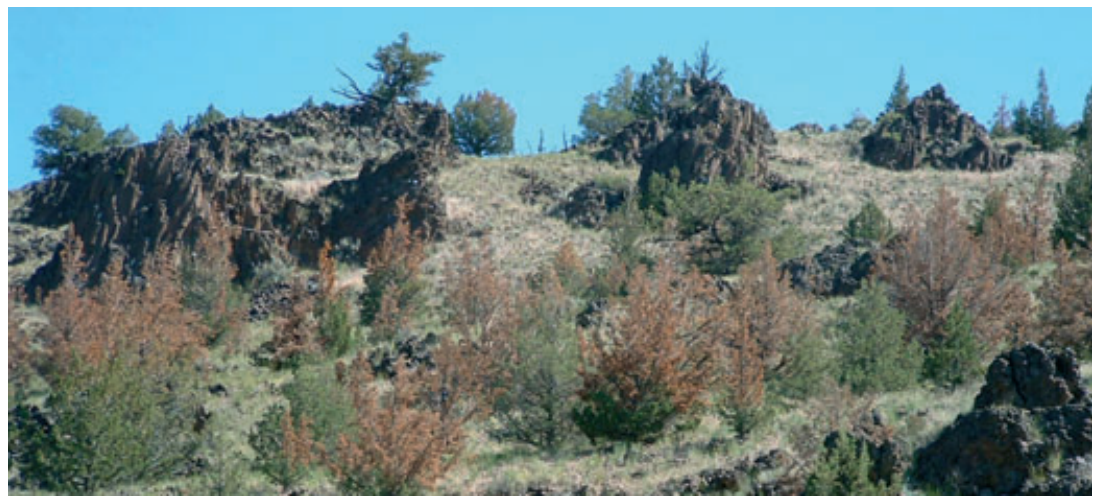

Figure 4 Establishment history of western juniper trees on disturbed and minimally disturbed (MD) sites. The percentage of trees established per decade from 1750 to 1960 is shown along with the percentage of trees established in all decades prior to 1750 .

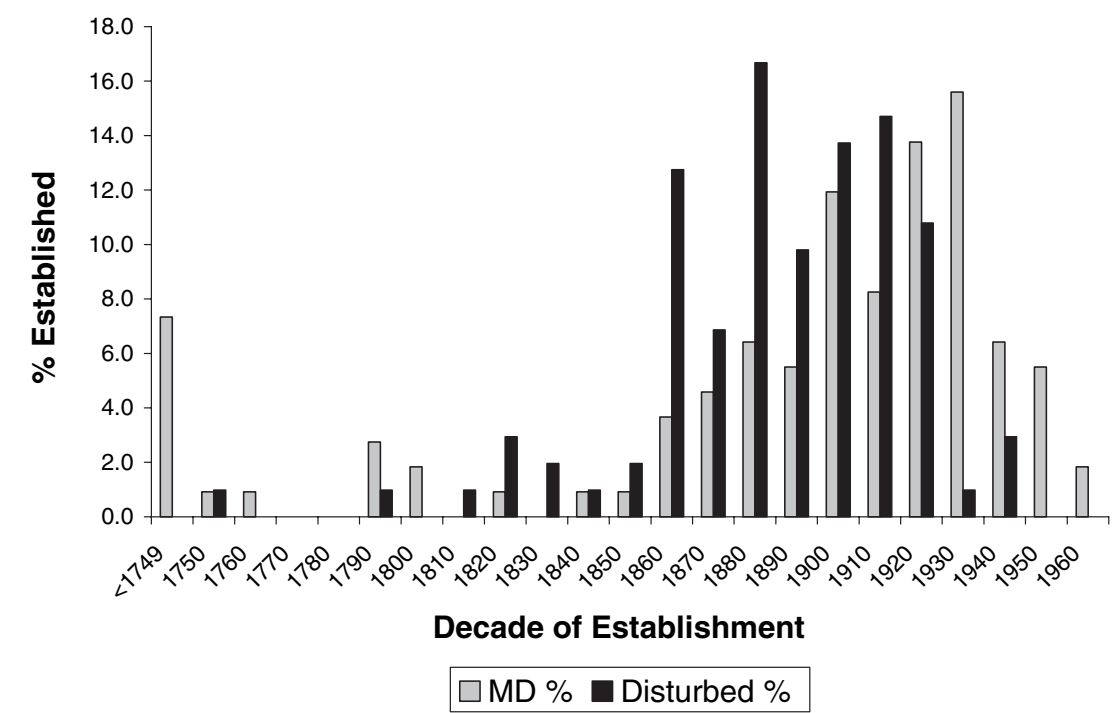

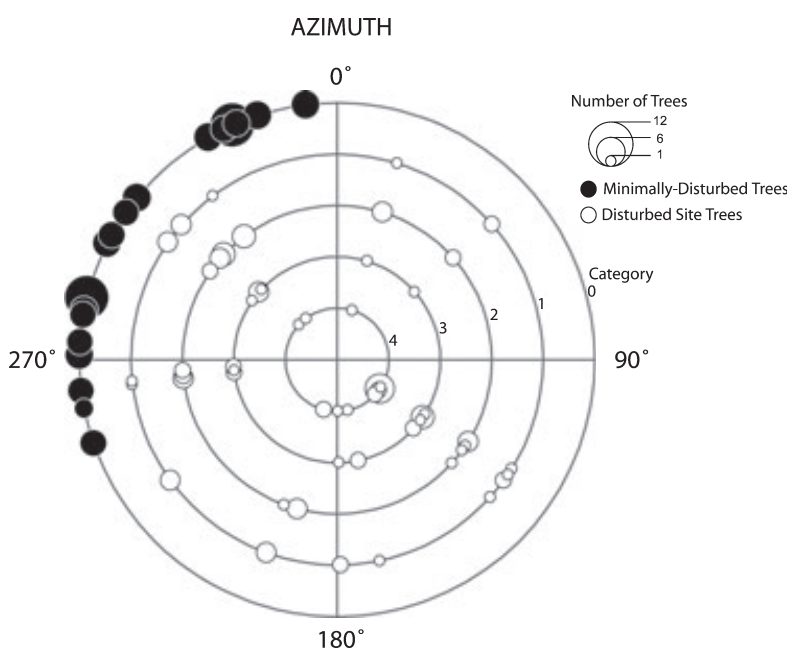

Figure 5 Occurrence of minimally disturbed $(\bigcirc)$ and disturbed (a) western juniper trees based on aspect and level of foliar damage. Circles closer to the centre indicate a higher disturbance category $(0=<10 \%$ foliar damage, $1=10-25 \%, 2=26-50 \%$, $3=51-75 \%, 4=76-100 \%)$. to $353^{\circ}(\mathrm{NNW})$, indicating that trees having other aspects were unable to avoid more substantial damage from the cold event. Conversely, the aspect distribution of disturbed-site trees was less pronounced (Fig. 5). The most common aspect was southeast, while north-east was the least common. Aspect was also associated with the severity of foliar damage, as nearly threequarters of the category 4 (> 75\% damage) trees had a southeasterly aspect.

For the disturbed-site trees, the only additional significant morphological or topographical difference between trees in the four disturbance categories was for slope $(P=0.011$, mean slope angle $=14.2,10.6,7.3$ and $6.8^{\circ}$ for category $4,3,2$ and 1 trees, respectively). Overall, there were more damaged trees of all categories found on gentle $\left(<10^{\circ}\right)$ slopes $(70.6 \%$ of damaged trees) compared with steeper slopes $\left(\geq 10^{\circ}\right.$ slope $)$ (Fig. 6). However, trees found on the steeper slopes were more likely to have greater foliar damage. For example, $83.3 \%$ of the trees found on $>20^{\circ}$ slopes had between $51 \%$ and $100 \%$ foliar damage (category 3-4) compared with $30.5 \%$ of the same damage-category trees on the shallower $\left(<10^{\circ}\right)$ slopes.

Soil textures at seven of the eight sites were various types of loam, with ashy sand at the eighth site (BCC) (Table 1). 


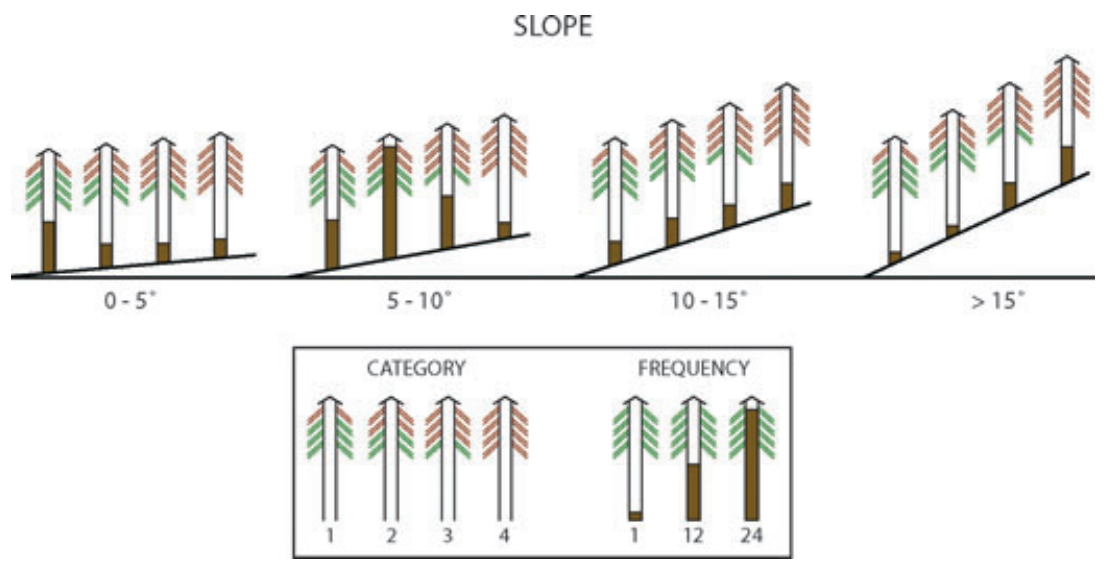

Figure 6 Occurrence of foliar damage by slope category for disturbed sites based on the level of observed foliar damage ( $1=10-25 \%$ foliar damage, $2=26-50 \%$, $3=51-75 \%, 4=76-100 \%)$.
Overall, the soils tended to be very coarse texturally, derived from volcanic materials and with near-neutral $\mathrm{pH}$. All four of the disturbed sites plus SCC had soils with mesic temperature regimes, while the remaining three $\mathrm{MD}$-site soils had frigid temperature regimes.

\section{DISCUSSION}

Our results suggest that a suite of environmental factors, working either individually or in concert, contributed to the damage and/or mortality of the trees and can be attributed to three broad categories: (1) biological/morphological, (2) topoedaphic and (3) climatological via drought stress. We discuss each of these in turn and then present the ecological implications of the event.

\section{Biological factors}

Our data show that susceptibility of western juniper to exceptionally cold temperatures is related to tree morphology, as MD-site trees were significantly shorter and wider than trees we sampled on disturbed sites, regardless of other topoedaphic considerations. Within the geographical range of western juniper, it is highly likely that significant genetic diversity exists within local populations, with phenotypic expressions commonly differentiated by tree form (Westfall \& Millar, 2004). Based on over a decade of field observations and dendroecological sampling of western juniper, we have rarely found the tallest trees to be the oldest of the local population. Rather, the oldest trees typically are those individuals of medium height and larger basal area.

The significance of tree morphology may be that the branches above the point where freeze-induced cavitation occurred can no longer easily extract water from the xylem below, causing these branches to dessicate and die. As the amount of xylem tension increases with tree height (Ryan \& Yoder, 1997), the susceptibility of taller individuals to watercolumn failure also increases, a finding consistent with our results. Further, while xylem repair is possible, the exceptionally dry soil-moisture conditions in the spring and summer of 2003 provided unfavourable conditions for recovery to occur.
Minimally disturbed sites had a significantly lower tree density and greater tree-age variance, and were older, whereas disturbed sites had higher density and were more evenly aged. These characteristics are typically found in the core areas of historical western juniper populations, rocky outcrops where fires do not easily spread, and at higher elevations where the combination of cooler autumn temperatures (which trigger the cold hardening process) and reduced soil-moisture stress make individual trees less prone to cavitation. Thus suitable environments for long-lived individuals and the occasional opening for seedlings are provided within the MD sites, creating the great variance in tree ages. Conversely, the disturbed sites were generally found in the more emergent western juniper woodlands characterized by either aspectenhanced soil-moisture stress or extreme temperature minima associated with cold air drainage, processes that invoke higher rates of mortality/dieback.

\section{Topoedaphic controls}

Aspect was the most dominant factor in the distribution of disturbed and MD trees. While no MD trees were sampled with aspects other than westerly to north-westerly, disturbed trees were sampled on slopes with predominantly southerly to south-easterly aspects (Fig. 5). This finding was best expressed for the most severely impacted trees (category 4). Our results suggest that, while trees could be affected regardless of aspect, only the westerly to north-westerly aspects provided conditions that minimized either dieback or mortality. While the importance of aspect has helped explain the differential susceptibility of forested environments to a suite of disturbances, including ice storms (Millward \& Kraft, 2004), wind storms (Boose et al., 1994) and fire (Beaty \& Taylor, 2001), our results indicate that the impacts of cold can also influence susceptibility. As western juniper can withstand exposure to temperatures far exceeding the October freeze, it appears that the individuals damaged had not undergone sufficient cold hardening prior to the freeze. We postulate that western juniper trees growing on the westerly, and particularly northwesterly, slopes were more advanced in the cold-hardening process because these slopes are both shaded in the morning 
and have colder soil temperature regimes than any other aspect.

The role of edaphic conditions affecting dieback is less clear, because this relationship is also associated with slope. Three of the four MD sites had soils with frigid temperature regimes on predominantly westerly to north-westerly aspects, while all four disturbed sites had soils with mesic temperature regimes and were typically located on slopes with southerly aspects. We posit that individuals located on slopes with westerly to northwesterly aspects were exposed to longer periods of minimum air temperatures and colder soil temperatures. On the southerly to south-easterly slopes, early morning solar radiation would warm the air more rapidly and soil temperatures would be comparably warmer.

Because emergent juniper woodlands typically have a high density of trees and are found downslope from the core areas of historical western juniper populations, the greatest number of trees with foliar damage were found on gentle $\left(<10^{\circ}\right)$ slopes.

However, within the disturbed sites we found that a greater percentage of trees growing on steeper, typically southerly, slopes were more prone to dieback because the slope angle intensified the amount of solar radiation, delaying the onset of cold-hardening. On steeper slopes, higher rates of precipitation runoff to percolation would further intensify soil moisture stress. This relationship is particularly remarkable for individuals located on slopes of $>20 \%$ (Fig. 6).

\section{Drought stress}

During the 2 years before, and continuing for 2 years after the 2002 freeze event, extreme drought conditions existed in the region (Oregon Division Seven), with annual Palmer Drought Severity Index values less than -2 (moderate to extreme drought) from 2000-04 (NCDC, 2002). While it is likely that drought accentuated the effects of cavitation associated with the freeze, a finding demonstrated with other Juniperus species (Willson \& Jackson, 2006), it is unlikely that the observed foliar damage to western juniper would have been visible in spring 2003 if the freeze had not occurred. Several observations support this contention. Comparable severe droughts in the same region have been concurrent with rapid expansion of the species (Knapp et al., 2001, 2002; Soulé et al., 2004), and western juniper trees growing in areas where the freeze was not as extreme were not affected (see Fig. 3 in Knapp \& Soule, 2005) despite similar drought conditions. Further, the visible damage occurred after the freeze, and damaged trees were still growing (producing annual growth rings) in 2003 and 2004.

\section{Ecological implications}

The removal of juniper can affect overland flow, stream flow, rates of erosion and effective precipitation (Miller et al., 2005), but these effects may be spatially varied because of variability in precipitation totals and seasonality, soil type and soil depth (Belsky, 1996). In south-eastern Oregon, Pierson et al. (2003) compared erosion, infiltration and runoff rates between plots of cut and uncut western juniper woodlands, and found that uncut plots had higher rates of runoff and erosion, and lower rates of infiltration. The amount of precipitation stored in the soil after a precipitation event (effective precipitation) has also been shown to be significantly reduced by western juniper woodlands (Miller et al., 2005), and reports from private landowners support these findings as the removal of trees has raised the water table in areas where western juniper density has been reduced (Whalen, 2006). Reductions in the aboveground live biomass of western juniper related to the October 2002 freeze event should serve to reduce the demand for soil moisture, which may be a net benefit for ecosystem processes within the severely affected regions.

Much of the research on western juniper during the past two decades has focused on both the causes and consequences of afforestation (Miller \& Wigand, 1994; Miller \& Rose, 1995; Soulé \& Knapp, 2000; Wall et al., 2001; Soulé et al., 2004), with a special emphasis on anthropogenic controls. Yet the 2002 freeze event suggests that a natural, large-scale element of self-regulation may exist that controls the population by selectively killing individuals in the areas where they have established more recently. Events such as this freeze may help explain the geographical patterns of western juniper occurrence in the interior Pacific Northwest and why this species, for example, is less common in the High Desert ecological province of south-eastern Oregon (Fig. 2). Although western juniper trees grow in regions of comparable aridity in Oregon, the High Desert is colder, thus the species is principally found in upland environments (Anderson et al., 1998) where it escapes the extremely cold air that pools in basins.

The freeze event may also explain large-scale disturbances seen within the western juniper range. For example, a majority of trees that have been sampled throughout the range of western juniper exhibit heart rot dating back to $c$. 1730-49 (Knapp \& Soulé, 1999). The most likely explanation for the heart rot, which requires an entry point on the tree for the fungus to invade, was identified as a widespread climatic event such as a wind storm or ice storm (Knapp \& Soulé, 1999). It appears possible now that an alternative event, such as a major freeze, could be linked to a regional-scale heart-rot episode, suggesting that a self-regulating event can occur that halts or slows down juniper expansion into the most frost-prone areas.

The freeze of October 2002 affected $c .75 \%$ of the western juniper range in the interior Pacific Northwest, causing foliar damage or mortality to $c .3 \%$ of the population at geographically specific sites. The impact on trees was not uniform, but rather selectively affected younger individuals growing: (1) on southerly aspects, (2) on steeper slopes, (3) among greater tree densities, and (4) with taller and narrower morphologies. Specifically, the consequences of the extreme freeze were spatially complex and 'serve(d) as a catalyst for sudden and unexpected changes' to the western juniper woodlands of the interior Pacific Northwest, thus meeting the criteria for classification as a large, infrequent disturbance (Turner \& Dale, 1998: 494). In this instance, the event principally resulted in the reduction of populations that had established within the 
past 150 years in sites that were less optimal for longevity than the core areas of historical western juniper populations. As such, this event exacted a long-term influence on western juniper trees growing within the marginal sites of their local populations.

\section{ACKNOWLEDGEMENTS}

The project was supported by a grant from the University Research Council at Appalachian State University and a Research Initiation Grant from Georgia State University. We are grateful for the help of Ron Halvorson of the Prineville, Oregon BLM office who initially identified multiple sites where the freeze effects were prominent, and offered insights on western juniper biology. We thank former graduate students at Appalachian State University and Georgia State University, J. Greg Dobson and Jeff Johnson, respectively, for their assistance in the field and laboratory, and Scott Davis for his assistance with the GIS analyses. The cartographic work was completed by Jason Marshall.

\section{REFERENCES}

Anderson, E.W., Borman, M.M. \& Krueger, W.C. (1998) The ecological provinces of Oregon: a treatise on the basic ecological geography of the state. Oregon Agricultural Experiment Station SR 990, Corvallis.

Applequist, M.B . (1958) A simple pith locator for use with offcentre increment cores. Journal of Forestry, 56, 141.

Beaty, R.M. \& Taylor, A.H. (2001) Spatial and temporal variation in fire regimes in a mixed conifer forest landscape, southern Cascades, California, USA. Journal of Biogeography, 28, 955-966.

Bedell, T.E., Eddleman, L.E., Deboodt, T. \& Jacks, C.C. (1993) Western juniper: its impact and management on Oregon rangelands. Oregon State University Extension Service EC 1417, Corvallis.

Belsky, J.A. (1996) Viewpoint: Western Juniper expansion: A threat to arid northwestern ecosystems? Journal of Range Management, 49, 53-59.

Boose, E.R., Foster, D.R. \& Fluet, M. (1994) Hurricane impacts to tropical and temperate forest landscapes. Ecological Monographs, 64, 369-400.

Dale, V.H., Crisafulli, C.M. \& Swanson, F.J. (2005) 25 years of ecological change at Mount St Helens. Science, 308, 961-962.

Davis, S.D., Sperry, J. S. \& Hacke, U.G. (1999) The relationship between xylem conduit diameter and cavitation caused by freezing. American Journal of Botany, 86, 1367-1372.

Gedney, D.R., Azuma, D.L., Bolsinger, C.L. \& McKay, N. (1999) Western juniper in eastern Oregon. General Technical Report PNW-GTR-464. USDA Forest Service, Portland.

Geo Community (2006) Geo Community, Niceville, FL. http:// data.geocomm.com.

Grissino-Mayer, H.D. (2001) Assessing crossdating accuracy: a manual and tutorial for the computer program COFECHA. Tree-Ring Research, 57, 205-221.
Holmes, R.L. (1983) Computer-assisted quality control in treering dating and measurement. Tree-Ring Bulletin, 43, 69-78.

Knapp, P.A. \& Soulé, P.T. (1999) Geographical distribution of an 18th century heart rot outbreak in western juniper (Juniperus occidentalis ssp. occidentalis Hook). Journal of Arid Environments, 41, 247-256.

Knapp, P.A. \& Soulé, P.T. (2005) Impacts of an early season freeze event in the interior Pacific Northwest (October 30thNovember 3rd, 2002) on western juniper woodlands. Journal of Applied Meteorology, 44, 152-1158.

Knapp, P.A., Soulé, P.T. \& Grissino-Mayer, H.D. (2001) Postdrought growth responses of western juniper (Juniperus occidentalis var. occidentalis) in central Oregon. Geophysical Research Letters, 28, 2657-2660.

Knapp, P.A., Soulé, P.T. \& Grissino-Mayer, H.D. (2002) Climatic regionalization and the spatio-temporal occurrence of extreme single-year drought events (1500-1998) in the interior Pacific Northwest, USA. Quaternary Research, 58, 226-233.

Martinez-Vilalta, J. \& Pockman, W.T. (2002) The vulnerability to freezing-induced xylem cavitation of Larrea tridentate (Zygophyllaceae) in the Chihuahuan Desert. American Journal of Botany, 89, 1916-1924.

Miller, R.F. \& Rose, J.A. (1995) Historic expansion of Juniperus occidentalis (western juniper) in southeastern Oregon. Great Basin Naturalist, 55, 37-45.

Miller, R.F. \& Rose, J.A. (1999) Fire history and western juniper encroachment in sagebrush steppe. Journal of Range Management, 52, 550-559.

Miller, R.F. \& Wigand, P.E. (1994) Holocene changes in semiarid pinyon-juniper woodlands. BioScience, 44, 465-474.

Miller, P.M., Eddleman, L.E. \& Miller, J.M. (1995) Juniperus occidentalis juvenile foliage: advantages and disadvantages for a stress-tolerant, invasive conifer. Canadian Journal of Forest Research, 25, 470-479.

Miller, R.F., Bates, J., Eddleman, L., Pierson, F. \& Svejcar, T. (2005) Biology, ecology, and management of western juniper (Juniperus occidentalis). Technical Bulletin 152. Oregon State University Agricultural Experiment Station, Corvallis.

Millward, A.A. \& Kraft, C.E. (2004) Physical influences of landscape on a large-extent ecological disturbance: the northeastern North American ice storm of 1998. Landscape Ecology, 19, 99-111.

National Climatic Data Centre (2002) Time bias-corrected divisional temperature-precipitation-drought index. Documentation for dataset TD-9640. Available from DBMB, NCDC, NOAA, Asheville, NC, USA. http://www.cdc.noaa. gov/cgi-bin/Timeseries/timeseries1.pl

NRCS (2003) Natural Resources Conservation Service, Oregon. http://www.or.nrcs.usda.gov

Phipps, R.L. (1985) Collecting, preparing, crossdating, and measuring tree increment cores. Water Resources Investigations Report 85-4148. US Geologic Survey, Reston, VA.

Pierson, F.B., Jr, Bates, J.D. \& Svejcar, A.J. (2003) Long-term hydrologic recovery following removal of western juniper. 
Meeting Abstract. Society for Range Management, Casper, WY.

Pittermann, J. \& Sperry, J.S. (2006) Analysis of freeze-thaw embolism in conifers. The interaction between cavitation pressure and tracheid size. Plant Physiology, 140, 374-382.

Ryan, M.G. \& Yoder, B.J. (1997) Hydraulic limits to tree height and tree growth. BioScience, 47, 235-242.

Savonen, C. (2003) Fall freeze cause of spring's western juniper damage and dieback. Oregon State University News \& Communication Services. http://oregonstate.edu/dept/ncs/ newsarch/2003/May03/juniper.htm

Sharrow, S.H. (2004) Cavitation may explain winter damage to rangeland vegetation. The Grazier, 321, 5-7.

Soulé, P.T. \& Knapp, P.A. (2000) Juniperus occidentalis (western juniper) establishment history on two minimally-disturbed research natural areas in central Oregon. Western North American Naturalist, 60, 26-33.

Soulé, P.T., Knapp, P.A. \& Grissino-Mayer, H.D. (2004) Human agency, environmental drivers, and western juniper establishment during the late Holocene. Ecological Applications, 14, 96-112.

Stone, R. (1998) Yellowstone rising again from ashes of devastating fires. Science, 280, 1527-1528.

Turner, M.G. \& Dale, V.H. (1998) Comparing large infrequent disturbances: what have we learned? Ecosystems, 1, 493-496.

Turner, M.G., Romme, W.H. \& Tinker, D.B. (2003) Surprises and lessons from the 1988 Yellowstone fires. Frontiers in Ecology and the Environment, 1, 351-358.

Wall, T.B., Miller, R.F. \& Svejcar, T.J. (2001) Juniper encroachment into aspen in the Northwest Great Basin. Journal of Range Management, 54, 691-698.
Westfall, R.D. \& Millar, C.I. (2004) Genetic consequences of forest population dynamics influenced by historic climatic variability in the western USA. Forest Ecology and Management, 197, 159-170.

Whalen, A. (2006) Are juniper trees loving Oregon to death? The Forest Log, 75, 4-7.

Willson, C.J. \& Jackson, R.B. (2006) Xylem cavitation caused by drought and freezing stress in four co-occurring Juniperus species. Physiologia Plantarum, 127, 374-382.

Yamaguchi, D.K. (1991) A simple method for cross-dating increment cores from living trees. Canadian Journal of Forest Research, 21, 414-416.

Peter Soule is a professor in the Department of Geography and Planning at Appalachian State University. Over the past decade he has been examining issues related to the driving forces behind observed changes in western juniper and ponderosa pine ecosystems.

Paul Knapp is a professor and director of the Carolina TreeRing Science Laboratory in the Department of Geography at the University of North Carolina-Greensboro. His interests have focused on the paleoecological dynamics of western juniper woodlands and ponderosa pine forests. 